\title{
PIOTR WIŚNIEWSKI
}

Zaklad Botaniki Og. Uniw.

Stef. Batorego w Wilnie.

\section{NIENOTOWANE STANOWISKA KILKU RZADSZYCH KRAJOWYCH I ZAWLECZONYCH ROŚLIN W WILEŃSZCZYŹNIE.}

Neue Standorte gewisser seltener einheimischer sowie eingeschleppter Pflanzen in der Gegend von Wilno.

W ciagu ostatnich paru lat ustaliłem występowanie w rozmaitych miejscowościach Wileńszczyzny szeregu rzadszych roślin. Wykaz ich podaję poniżej według miejscowości. Pozatem osobno podaje rozmieszczenie Nymphaea candida Presl. Najbliższe okolice Wilna: Salvia glutinosa L.-zbierałem na Górze Trzykrzyskiej w końcu września 1933 r. Miejsce znalezienia tej rośliny mogłoby wskazywać na jej pochodzenie $\mathrm{z}$ dawnego Ogrodu Botanicznego. W zielniku dawnego Uniwersytetu Wileńskiego, w którym znajduje się caly szereg roślin z adnotacją, że pochodzą z Ogrodu Botanicznego - rośliny tej nie znalazłem.

Oczywiście nie dowodzi to jeszcze, że w dawnym Ogrodzie Botanicznym jej nie było. Na niżu Salvia glutinosa występuje w południowej części Polski, jednak dalej na wschódw Rosji notowana była i więcej na północ, mniej więcej na tej samej szerokości geograficznej, na jakiej znajduje się Wilno. Aster salignus Willd. - brzeg Wilji, mniej więcej naprzeciw Szpitala dla chorób zakaźnych. Zb. we wrześniu 1934 r. 
Impatiens parviflora DC. Z parcelki ogródka przy Zakładzie Botaniki Ogólnej przeniosła się do parku przy tymże Zakładzie, a następnie rozpowszechniła - na sąsiednie tereny.

An towil: Amelanchier canadensis v. spicata Sarg. Kilka gałązek tego krzewu, znalezionego nad jeziorem Antowilskiem, było mi dostarczone przez p. S. z prośbą o określenie z nadmienieniem, że krzew ten bardzo licznie występuje w Antowilu.

Po zbadaniu terenu na miejscu stwierdziłem, że Amelanchier istotnie rozrósł się tu wyjątkowo obficie i na dużej przestrzeni. Spotykałem go nad jeziorem Antowilskiem, jeziorkiem zwanem przez ludność miejscową „Półmisek”, (nad tem jeziorkiem znalazlem 1 okaz o pstrokatych liściach), oraz na południo-zachód od fermy Antowilskiej nad rzeczką Antowilką. Nad rzeczką tą występuje w zaroślach na jej wschodnim wysokim brzegu. Pojedyńcze egzemplarze spotykałem tu w cdleglości około jednego kilometra od fermy, a więc długość terenu, który zajmuje ta roślina wynosi conajmniej jeden klm. W niektórych miejscach występuje dość gęsto; tak naprzykład na niewielkiej stosunkowo przestrzeni w pobliżu jeziora Antowilskiego i jeziorka „Półmisek” naliczyłem zgórą 100 egzenıplarzy. Najwięcej stosunkowo okazów znalazłem na południowo-zachodniej stronie jeziora Antowilskiego, pomiędzy jeziorem i zabudowaniami fermy; występuje tu na torfiastym bogatym w próchnicę gruncie, wśród młodych zarośli powstałych na dawnej porębie leśnej i złożonych z brzozy, olchy, wierzb, czeremchy i t. p. Jak widzimy ta użyteczna i piękna roślina, w sprzyjających warukach dziczeje u nas stosunkowo latwo i sądzę, że zasługuje na szersze rozpowszechnienie ${ }^{1}$ ).

1) Przy oznaczeniu tej rośliny korzystalem z okazów zielnikowych laskawie mi wypożyczonych przez Zakład Systematyki roślin Uniwersytetu Warszawskiego oraz przez Muzeum Komisji Fizjograficznej P. Akad. Um. Pomiędzy okazami Amelanchier jakie otrzymalem z Muzeum Akad. Um. znalazłem w zielniku Wolos z c zak a parę okazów Amelanchier pod nazwą A. botryapium Ser. z adnotacją, że byly zbierane na Górze Trzykrzyskiej przez T. Sym on owi czówne w 1897 r. Z i ele n cew w swym wykazie flory Wileńszczyzny (r. 1890-92) nie wymienia tej rośliny, natomiast notuje na Górze Trzykrzyskiej Cotoneaster vulgaris, która, jak stwierdzilem, dotychczas tam występuje, ale mniej rzuca się w oczy niż Amelanchier. Być może więc, że w okresie kiedy $\mathrm{Z}$ i elencew prowadzil swoje obserwacje, roślina ta nie występowala jeszcze na tym terenie, lecz zjawila sic lub przynajmniej rozpowszechniła-znacznie później. 
Z innych roślin, jakie znalazłem w Antowilu zasługują na wzmiankę: na wschodnim brzegu rzeczki Antowili, na pd. wsch. od fermy:

Oxytropis pilosa (L) DC., niedaleko nowego osiedla włościańskiego,

Aster salignus Willd., bliżej zabudowań fermy,

Agrimonia pilosa Led. - w zaroślach niedaleko fermy; znajdowałem ją też na pagórku, przylegającym do jeziorka „Pólmisek”.

Puszcza Rudnicka: Lunaria rediviva L. - w pobliżu ujścia Małej Kiernówki do Wisińczy $\left.{ }^{1}\right)$. Tworzy tu na skraju lasu przy łączce przylegającej do Wisińczy, wyspę mającą około $80 \mathrm{~m}$. długości i około $25 \mathrm{~m}$. szerokości; prawie na całym tym terenie występuje obficie i gęsto.

Teren ten jest wilgotny, bogaty w próchnicę, pokryty lasem świerkowym z nieznaczną domieszką czarnej olchy; pozatem występują tu bardzo rzadko małe okazy: Sorbus aucuparia L.; z krzewów znalazłem tu: Corylus asellana L., Rubus idaeus L. oraz w niewielkiej ilości Ribes rubrum L. i Evonymus europaea L. Z zielnych roślin ustalić mogłem w końcu okresu wegetacyjnego 1934 r. następujace ${ }^{2}$ ):

Oxalis acetosella L., Urtica dioica L., Chrysosplenium alternifonium L., Glechoma hederacea L., Galeobdolon luteum Huds., Mercurialis perennis L.; znacznie rzadziej znajdywałem Geum rivale L., Cardamine amara L., Geranium Robertianum L., Lathyrus vernus (L) Bernh. W tym samym lesie, ale już poza terenem zajętym przez Lunarję, pomiędzy innemi znalazłem jeszcze Lycopodium Selago L., Lycopodium annotinum L. i Gentiana pneumonanthe L.

Okolice Sól i Gudogaj: Andromeda calyculata L. na torfowisku wysokiem, położonem w niewielkiej odległości na północ od drogi, prowadzącej od wsi Zajeziercze do Babiej

1) Stwierdzenie tej rośliny zawdzięczam Panu Leśniczemu St. O 1 dakowi. W przewidywaniu, że roślina ta może występować w Puszczy Rudnickiej pokazalem p. O. kilka owoców Lunarji, po zapoznaniu się z któremi p. O. oświadczył, że roślina ta w P. R. znajduje się, a następnie dostarczyl mi łaskawie kilka okazów i wskazal miejsce jej występowania.

2) Ponieważ rośliny, towarzyszące Lunarji, moglem określać prawie wyłącznie jedynie tylko na podstawie organów wegetatywnych, nie sạ wykluczone nieścisłości w oznaczaniu. 
Łuży, w lasach dóbr B on if a cowo w miejscowości nazywanej przez miejscową ludność - „R a t a h o ly”. Zb. 30/VII $1934 \mathrm{r}$.

Botrychium matricariae Spreng. w tych samych lasach i przy tej samej drodze, co i poprzednia - bliżej wsi Zajeziercze. Zb. 30/VII $1934 \mathrm{r}$.

Botrychium lunaria (L). Sw. - w dużem zagłębieniu przy torze kolejowym Soły - Smorgonie, pomiędzy wsiami Gaucie i Lisiczyzna, niedaleko wsi Gaucie, na pólnocnej stronie toru. Zb. 29/VII $1934 \mathrm{r}$.

Ophioglossum oulgatum L. - przy tym samym torze, co i poprzednia, niedaleko wsi Lisiczyzna, na południowej stronie toru. Zb. 29/VII 1934 r.

Goodyera repens (L). R. Br. - w lesie szpilkowym na „Błocie Łopockiem” niedaleko Sól. Zb. 29.VII 1934 r., oraz w lesie pomiędzy Ostrowcem i stacją Gudogaje. Zb. 5/VII $1934 \mathrm{r}$.

Lycopodium inundatum L. - folwark Wiszniówka koło Sól w zagłębieniu, wykopanem przy układaniu toru kolejki przez wojska niemieckie w czasie wojny europejskiej. Zb. 28/VII $1934 \mathrm{r}$.

Lycopodium complanatum L. i Lyc. annotinum L. (owocujące) las pomiędzy Gudogajami i Ostroxcem. Zb. 5/VIII 1934 r.

Agrimonia pilosa Led. - majątek Male koło Ostrowca w wilgotnych zaroślach, koło strugi, odpływającej od stawu majątkowego, przy drodze do wsi Male. Zb. 5/VIII $1934 \mathrm{r}$.

Okolice Smorgoń: Andromeda calyculata L. - niedaleko wsi Martyszki, okaz dostarczony mi przez p. M. Wiśniewskiego.

Okolice Nowo-Święcian i Koltynian: Andromeda calyculata L. - we wsi Borówk a koło malego jeziorka tej samej nazwy, położonego przy drodze od Nowo-Święcian do Koltynian na torfowisku wysokiem, otaczającem jeziorko. Zb. 24/VII 1934 r.

Drosera longifolia L. - na tem samem torfowisku co i poprzednia. Zb. 24.VII $1934 \mathrm{r}$.

Lycopodium annotinum L. (owocujące) - w lasku szpilkowym, przylegającym do jeziorka Borówka. Zb. 24/VII $1934 \mathrm{r}$.

Stanowiska Nymphaea candida Presl - W Wileńszczyźnie dotychczas notowana była tylko Nymphaea alba L. Badając materjał białej lilji wodnej z kilku stanowisk, ni- 
gdzie nie stwierdziłem Nymphaea alba L., wszędzie natomiast znajdowałem Nymphaea candida Presl. Podaję tu wykaz miejscowości w których tę ostatnią znalazłem: 1) Stawek w Z akrecie koło Wilna; materjał dostarczony przez p. T. P a chniewskiego 26/VII 1934 r. 2) Jezioro Antowil - Zb. 8 IX 1934 r. 3) Jezioro Topie le kolo An towila; materjal dostarczony przez p. Mgr. M. Wierzbicką 20/VIII 1934 r. 4) Jezioro B o rów k a niedaleko Nowo-Święcian. Zb. 24/VII 1934 r. 5) Jezioro S a k 1 otis kolo Koltynian. Zb. 24/VII 1934 r. 6) Stawek w majątku Bujwidziszki pod Wilnem ${ }^{1}$ ). W czasie gromadzenia materjałów dotyczących rozmieszczenia białych lilji wodnych dowiedziałem się, że zainteresował się też tem zagadnieniem Prof. J. Trzebińs ki, który jak mnie objaśnił, również w szeregu miejscowości w Wileńszczyźnie znalazł Nymphaea candida Presl. Wnioskować z tego należy, że, jeżeli zasiąg Nymphaea alba L. dochodzi do Wileńszczyzny, to należy ona tu do rzadkich roślin, natomiast pospolicie występuje Nymphaea candida Presl.

\section{ZUSAMMENFASSUNG.}

Verfasser gibt einige neue Standorte gewisser seltener einheimischer sowie eingeschleppter Pflanzen in der Gegend von Wilno an $u$. a. für:

Andromeda calyculata L.

Oxytropis pilosa (L) DC.

Agrimonia pilosa Led.

Salvia glutinosa L.

Lunaria rediviva L. (mit einigen ihrer Begleitpflanzen),

Amelanchier canadensis v. spicata Sarg.

Impatiens parviflora DC. u. a.

Verfasser notiert auch einige Standorte von Nymphaea candida Presl und vermutet, dass allgemein in der Gegend von Wilno $N$. candida vorkommt, dagegen $N$. alba L., wenn sie überhaupt in genannter Gegend vorhanden sein sollte, so jedenfalls selten ist.

Institut $f$. allg. Botanik d. Unio. in Wilno.

1) Materjał ten otrzymałem z basenu Zakladu Biologji Ogólnej U.S.B.; według zapewnień p. Rajszysa, który roślinę tę w basenie zasadził, pochodziła ona ze stawku majątku Bujwidziszki. 